\title{
Mateship and egalitarianism in Henry Lawson's short stories
}

Déborah Scheidt $t^{a}$

\begin{abstract}
Mateship is an important element of the so-called "Australian Tradition" in literature. It consists of a particular bond between men who travel the rural areas known as "the bush" or "the outback". This article examines some of Henry Lawson's mateship stories, with a focus on the different connotations that the term can assume for the author, especially regarding the theme of egalitarianism. It considers how the Bulletin Magazine, which "discovered" Lawson and published many of his stories, had a role in fostering a special model of Australian democracy and a peculiar style for Australian literature. It also reflects on how the dissemination of Lawson's stories through periodicals in the last decades of the $19^{\text {th }}$ century helped create a feeling of what Benedict Anderson calls "nation-ness".
\end{abstract}

Keywords: Mateship. Egalitarianism. Henry Lawson. Australian short stories. 
Intense political and social changes in the second half of the $19^{\text {th }}$ century affected the course of democracy in Australia. The six colonies were involved in the discussion of a new constitution as they headed towards the federative system, an effort that gained momentum in the last decade of the century and was finally achieved in 1901. Tax and land reforms and the introduction of labour benefits, such as the regulation of working hours and retirement, and the payment of salaries to members of the Parliament, meant that society was becoming more egalitarian. Anticipation for change, however, shared space with the tension generated by differences of opinion and the possibility of imperial retaliation.

That was the prevailing atmosphere in the city of Sydney when Henry Lawson (1867-1922) made his first literary appearance in the local periodicals. Lawson was an introspective 20-year-old when his poem "The Song of the Republic" was accepted for publication in the Bulletin Magazine. That was the first of hundreds of pieces - poems, sketches, short stories and articles - that would make of him one of Australia's best-known writers.

As one of the most iconic and long-lasting Australian magazines, the Bulletin helped set the direction of Australian nationalism in the 1890s and in the first decades of the $20^{\text {th }}$ century. In a country with a large territory but incipient means of transportation, periodicals could penetrate the back lands with impressive regularity and foster the aggregating effect that Benedict Anderson has called "nation-ness". When groups of people scattered across a continental land mass read the same pieces of news and the same fictional stories (most of them set in Australia and depicting events that were familiar to the readers), they started to imagine themselves no longer as inhabitants of separate colonies with distinct governments and interests, but as part of a community that would eventually constitute a nation (ANDERSON, 2009, p. 80).

The proliferation of local publications created, according to H. M. Green (1968, p. 719-721), a healthy internal competition in Australia, while, at the same time, the patriotic feelings they inspired, propelled by the weakening of provincial rivalry and the advance of democracy, helped fight prejudice against the local cultural industry. For David Carter and Gillian Whitlock (1989, p. 111), the discussions proposed by the Bulletin about the 
role - at the same time local and "universal" - of culture and the rejection of the alleged cultural inferiority of Australia, placed the magazine among the most politically and socially engaged forms of mass media in Australia, at a time when literature was thought to have the double function of "civilising" and expressing the national identity of a new society.

The Bulletin accepted submissions from ordinary people as well as professional writers and was thus extremely popular among aspiring writers. J. F. Archibald, its editor-in-chief and co-founder, used to say that "[e]very man has at least one story in him" (ARCHIBALD apud PHILLIPS, 1970, p. 25). Its editorials promised that "[t]he Editor will carefully read and acknowledge in the 'Correspondence' column all contributions submitted" and those could be in several forms: "Political, Social or Other Articles, Verse, Short Tales or Sketches (those dealing with Australian subjects [...] are specially acceptable), Paragraphs, Letters, or Newspaper-clippings" (ARCHIBALD apud CARTER; WHITLOCK, p. 113). It also promoted literary contests, paid for contributions at the time of acceptance (rather than after publication) and provided support and sponsorship to writers that would become cultural icons in Australia.

Among its readers, the Bulletin became, in Palmer's (1954, p. 88) words, "a power in the community, almost an oracle for those who looked for guidance in national issues". The magazine was also what Sylvia Lawson (1987, p. 150) called a "print circus", displaying a great variety of text genres, styles and voices, arranged in a rather haphazard way, dealing with politics, social matters, business, entertainment, gossip, cultural criticism, women's matters, agriculture, the weather and in several formats: news, jokes, cartoons, poems, ballads, short stories, yarns, adverts, among others (CARTER; WHITLOCK, 1989, p. 114).

Sylvia Lawson also observes that the Bulletin's famous epithet "the bushman's Bible" was not so much due to the fact that the periodical tried to please rural readers by representing or mythicising their lifestyle

but rather because it brought the city and the globe to their doorsteps, and made them neighbours in print with the most famous of the wicked, the dazzling and the powerful. The people of the bush, and indeed of the back lane and factory also, were given back to themselves as citizens of the 
world. Their experience was validated, their places named as centres of event, so that as readers and reader-writers, the Australians of at least one generation were rescued from the second-rateness of exile (LAWSON, 1987, p. 194).

In the first years of its existence, in the 1880s, the Bulletin did not have a clear editorial policy in relation to its literary sections and had published typically Victorian serials, sentimental and moralising in tone, with plots set in Europe and adopting the artificial language imported from Britain. It was only after it perceived the potential of the popular literature that was a daily presence in the lives of itinerant bushmen, rural workers' campsites and shearers' sheds and after it started to view those people not only as a target-public but also as contributors, that it achieved its outstanding position in the formation of the so-called "Australian tradition" in literature (PALMER, p. 104-105), based mainly on ruralthemed short stories.

One example of the Bulletin's innovativeness was the mixing of the roles between contributors and readers. All contributions deserved a reply in the Correspondence section of the magazine and the rejections were often expressed in a comic tone. That was, according to Sylvia Lawson (1987), a clever marketing strategy, as even candidates whose texts were refused made a point of buying the magazine if only to see their names in print and have their few minutes of fame amongst neighbours and acquaintances (who would also feel inclined to buy copies).

For Carter and Whitlock (1989, p. 115), a defining characteristic of the Bulletin, was the fact that it worked as a mediator between editors, writers and readers, allowing for an unusual and even amusing "dialogue" between those groups. Instead of addressing a predetermined faction, the Bulletin created its reading public, by means of textual diversity and dialogue with readers. Although it had very specific political positions - defending federalism, republic, labour rights and opposing nobility titles, just to quote a few examples - the Bulletin mostly described itself as "national", "Australian" or "democratic", attracting readers of all persuasions.

It did not, according to Carter and Whitlock (1989, p. 122), act merely as a foil for a pre-conceived notion of Australia, but "[i]n establishing and sustaining a community of readers, 
a print community, the magazine for a certain period offered readers and writers the opportunity to participate in an imagined community, nationally conceived". And despite its opposition to the hegemonic power or the elites and the polemic nature or the discussions it promoted, the Bulletin

did not see its audiences in sectional terms but rather as the nation, the national interest, the people, categories which were nevertheless race and gender specific. The address to the readership occurred as much in the entertainment as in the political pages - indeed it might not always be easy to tell them apart. The Bulletin also drew into its pages material (and readers) from rural and provincial areas. It printed provincial matters side by side with reports of political and cultural events overseas. A community of readers existed at least in the pages of the magazine, a community defined locally and nationally, but not as parochial, exiled or colonial (CARTER; WHITLOCK, 1989, p. 123).

An important sign not only of the Bulletin's antiparochialism, but mainly of its openness to international cultural trends, can be found in its editorial guidelines to short fiction. By the end of the century, objectivity and conciseness had become Archibald's touchstones and his famous advice to new contributors was invariably "Boil it down!". The development of a "Bulletin style" was, according to A. A. Phillips (1966, p. 1), a true revolution in the literatures in English, pushing Australian short fiction towards modernism even before European or North American literature started to do so.

Influenced by the editorial policies of newspapers and magazines, Australian short stories should be, as Green puts it,

on the average the shortest of all short stories: sentences had to be brief and words must not be wasted; descriptive and explanatory matter must be cut to a minimum. Other requirements were simplicity, directness, realism and dramatic force (GREEN, 1968, p. 531).

As Brian Kiernan (1984, p. viii) observes, Lawson excelled on conciseness half a century before Hemingway would make minimalism famous worldwide. "A Love Story" was published in the Bulletin in 1893 and is so short that it can be entirely reproduced here:

"He went up-country and was reported dead," said the traveller to his mate, as they sat down on their swags. 
"He was reported to have been drowned while trying to swim his horses across a billabong. His girl broke her heart - and mended it again; then he turned up alive, and drier than ever, and married her, and broke her heart for certain. And - she died."

He spat in the dust and scraped it impatiently with his foot. "She was - she was an old sweetheart of mine," he said, speaking low and as if to himself.

He rested his long arm listlessly on his knee, and absently scraped a cross in the dust, between his feet, with the blade of a pocket knife.

"Ah, well - never mind... The billy's boiling, Joe." (LAWSON, 1984a, p. 300)

Accordingly, Colin Roderick (1985, p. 78) considers "A Love Story" a "miracle of compression", a narrative able to create, in very few words, "a world of imaginative reconstruction". Another evidence of Lawson's expertise as a storyteller is in the contrasts that the tale suggests. On the one hand are the travellers' roughness, their existence reduced to bare essentials, their language teeming with Australianisms related to the harsh background. The atmosphere created by their interaction, on the other, is lyrical and delicate and the reminiscence of lost love is only hinted at, more by the narrator's pauses and enigmatic gestures than by his actual words.

The characters in "A Love Story" are itinerant workers, recurring types in turn-of-the-century Australian literature. Not by coincidence, travelling has an important role in Anderson's theory of "nation-ness". An early example of (religious) imagined communities presented by Anderson are the pilgrimages of people from different locations and speaking different languages. These people met on their way to sacred places and forged a feeling of connection derived from a common creed. Similarly, while on the move from small European towns towards the metropoles to perform their professional duties, representatives of absolutist governments usually met a number of unknown "colleagues". In the feelings of interconnection that were generated during those trips, especially when the travellers spoke the same language, Anderson (2009, p. 95) locates the roots of the nationalist principle.

Centuries later, the movements of people in the Australian interior would have the same psychologically 
aggregating effect. Melissa Harper (2007, p. xiii) considers bushwalking and other forms of itinerancy as crucial factors for the imaginative processes of representation of identity in Australia, where travellers - convicts, explorers, immigrants, miners, bushrangers - and a whole plethora of workers and wanderers - swagmen / sundowners ${ }^{1}$, shearers, drovers, station hands and stockmen - ended up crossing each other's paths and interacting in campsites, farmyards and shearing sheds, creating a perception of nation.

For Russel Ward (1966, p. 3), who in the 1950s published The Australian Legend, an influential study on the origins of Australian identity, the itinerant seasonal workers who wandered back and forth outback villages, rural properties and coastal towns had an important role in mythicising the figure of the bushman. These workers' semi-nomadic lifestyle contributed to the spreading of stories, "yarns", bush ballads and popular poetry in which bushmen appeared as protagonists and heroes. In the "Australian tradition", the bushman was tenacious, adaptable and skilled at facing the huge distances, dryness and loneliness of the Australian back lands. He was, thus, deemed superior to urban dwellers, becoming a symbol of Australianness, even though historically Australia has always been an urban society, with most of its population clustering around a few big cities, all located on the coast.

Gregariousness was an important factor for bush travellers and rural workers in $19^{\text {th }}$ century Australia, as journeying the outback unaccompanied or being left alone on isolated farms for a long period of time might pose a threat to one's physical health and mental sanity. One way of avoiding those perils was forming "a bond between equal partners" (The Australian National Dictionary apud MOORE, 2008, xv, p. 104), or a "mode of pure masculine camaraderie" (GOODALL, 1995, p. 88) known as "mateship". Lawson's "A Love Story" shows one of the most sentimental aspects of mateship in action: bush workers sharing a story (or "spinning a yarn" in Australian colloquial language) around a camp fire.

The ability to share is one of the main tenets of mateship. Ward's definition of a mate was someone with whom a man could share "money, goods, and even secret aspirations and for whom even when in the wrong, he was prepared to make 
almost any sacrifice" (WARD, 1966, p. 99). From a political point of view, Phillips (1970, p. 13-17) equates mateship to the third element of the French Revolution triad. Nineteenth century Australians would prefer "mateship" to "fraternity", a more practical and less artificial or Europeanised term to describe the spirit of cooperation in the new democratic society they believed they were promoting. The concept of mateship carried, thus, a great deal of idealisation, and became a favourite among Australian authors in their intent to express anti-British, egalitarian tendencies and the Australianness of their background.

In the Australian imagination, Henry Lawson's name is almost synonymous with mateship. Harry Heseltine claims that, for most Australians, more than being the great propagator of the theme, Lawson would have "preached the gospel of mateship":

\begin{abstract}
Lawson may almost be said to have invented mateship; he certainly made the subject peculiarly his own. And in taking mateship as a major theme of his fiction, so runs the received scripture, he gave us a uniquely Australian vision, a vision of a happy band of brothers marching bravely forward to a political and social Utopia, united in their hatred of tyranny, their love of beer, their rugged manliness and independence (HESELTINE, 1972, p. 342).
\end{abstract}

But despite this generalising view, Heseltine claims that Lawson's approach to mateship was unique because, far from adopting a single-minded, idealistic view on the subject, he revealed several of its connotations in his stories. The importance of mateship - as well as the consequences of its absence - is presented in Lawson's sketch "Rats" ("ratty", in Australian English, means "eccentric", "slightly mad"), in which three travellers (mates) come across what they believe to be two men fighting. When they try to intercede, they notice that, in fact, there is only one man beating up his swag (a traveller's belongings wrapped up in a blanket is known in Australia as a "swag"). The travellers watch the man's behaviour for a while and even encourage Rats's folly. They leave some food, money and advice and move on, while Rats, holding a fishing line, attempts to catch a fish from a hole on the road. 
For Heseltine, implicit in this sketch is Lawson's own opinion in relation to survival in the Australian interior:

Any single-handed attempt to cope with the bush will almost inevitably end in a deranged capering in the dust - Lawson's theme is almost as simple as that. In the face of such circumstances, some sort of shared life is obviously imperative. Marriage seems to be quite unsustainable by most of Lawson's characters; it drives them to drink and the track. So the only thing left is the society of your fellow wanderers in the outback - in a word, mateship (HESELTINE, 1972, p. 347).

Another "ratty" and even lonelier character that corroborates the argument expressed above is the protagonist of "The Bush Undertaker", an old shepherd who spends most of the time isolated in the bush, drinking rum and looking after sheep with the help of his dog Five Bob. The story is centred around the bushman's attempt to keep the tradition of mateship as he comes across a mate of his, Brummy, in the form of a mummified body - due, according to the protagonist's own theory, to the action of sunlight, for about three months, over Brummy's rum impregnated cadaver. While continually talking to Brummy, to Five Bob and to himself, the old shepherd goes through a great deal of effort to move the body to his hut, where he performs "the last rites".

The success of this story lies in Lawson's skill in creating a game of contrasts, as the story is at once tragic and comic, matter-of-fact and affectionate. For the protagonist, immersed in the brutalising routine of bush life, finding Brummy and facing the possibility of his own lonely death are not causes for great concern. At the same time, the care with which he tends his mate's body and the tone of his monologues / dialogues are proof that his humanity is not altogether lost. The contrast between the protagonist's attempts at formality and his broad Australian "lingo" is very effective in creating the intended humour:

Once or twice he muttered the words, "I am the rassaraction." [...] [H]e was evidently trying to remember the something that ought to be said. He removed his hat, placed it carefull on the grass, held his hands out from his sides and a little to the front, drew a long deep breath, and said with a solemnity that greatly disturbed Five Bob, "Hashes ter hashes, dus ter dus, Brummy, - an' - an' in hopes of great an' gerlorious rassaraction!' (LAWSON, 1984a, p. 247-248) 
"The Bush Undertaker" and, to a lesser extent, "Rats" parody the efficacy of mateship both as an antidote against loneliness and as a way of sharing the experiences of bush life. Heseltine (1972, p. 343) argues that while the theme of mateship is present directly or indirectly in most, not to say all, of Lawson's stories, it does not always appear in an idealised and politicised manner, or as a "code of behaviour" for the bushman, as the blind "idolatry" of Lawson as the central figure in the "the Australian legend" might imply. The critic perceives, from a careful analysis of the stories, that they can reveal varied and even contradictory - if not frankly objectionable - aspects of mateship (i.e., the three travellers encourage Rats' schizophrenic outbreak for their own amusement).

The "aura" created around Lawson regarding his view of mateship is certainly due to narratives such as "Send Round the Hat". This would be, according to Colin Roderick (1985, p. 233), "the key story in Lawson's illustration of his ideal ethic", or the subordination of individual interests to the community's wellbeing, which he classifies as "social humanism" (RODERICK, 1966, p. 59), or Australia's idiosyncratic concept of socialism put into practice.

The story starts with a description of a group of men (all of them having peculiar nicknames such as "One-eyed Bogan", “Jack Moonlight", "Gentleman-Once" e "Barcoo-Rot”) in the morning after a "spree" (the common practice among Australian rural workers of spending most of their wages, immediately after pay day, on drinking and gambling). The narrator and his mates are woken up from their hangovers by the shearer Bob Brothers, better known as "the Giraffe", acting on one more of his fund-raising campaigns. Irritated at first by Giraffe's insistence, the narrator comes, as the plot develops, to admire Giraffe's helpfulness and generosity. Giraffe is a small-town problem solver, known for his typical gesture of passing round a tattered hat to collect money for anyone in need. His empathy for the Other overcomes his unionist loyalty, and the beneficiaries of his campaigns also include people considered undesirable, such as prostitutes or non-unionised and, therefore, cheaper Afghan immigrants, brought to the outback to drive camels who, supposedly, stole jobs from "Australians". 
It is important to notice that the characterisation of Giraffe defies the hegemonic racist, xenophobic and misogynist views of Lawson's unionist companions and even that of the Bulletin, whose mottos were "Australia for Australians" and later one "Australia for the white man". For Michael Wilding (1993, p. 19), this episode serves as a counter-argument for critics who generalise Lawson's work as racist or even fascist. For Wilding, Lawson's stories would be representing a racism that already existed in Australian society, due to labour policies that introduced non-unionised (usually Asian) workers, in a system of semi-slavery, with the express aim of weakening union movements. Other stories, such as "Send Round the Hat", were somehow trying to overcome that racism.

The story ends with the mates sending round the hat to collect money for Giraffe's wedding. What Wilding (1993, p. 19) calls "organized co-operative mateship" is revealed along the story in the fact that all the mates, no matter how bad their financial situation or annoyance with Giraffe's persistence is, make an effort to contribute to his causes, and their explicit recognition, in the "happy ending", of Giraffe's generosity. The "social and political utopia" mentioned by Heseltine acquires local colours, as it becomes mixed to the ironic tone of the narrative and the characters' mischief and small vices (more on the part of the mates, with their inconsequent behaviour which includes swearing, gambling and drinking, than on the part of the naïve and teetotal Giraffe).

Drinking is an important component of mateship in Lawson's stories and has a central role in "Telling Mrs. Baker", a story built around the dilemma of the drovers Jack (the narrator) and Andy. Before setting out on a two-year-long trip to the north of Australia, driving a herd of cattle, Andy promises his boss's wife, Mrs. Baker, to keep an eye on her husband, a well-known alcoholic. However, the mates can do little to stop Bob Baker's progressive physical, mental and moral dissolution, which culminates with the three of them being fired from the job.

"We could have started on the back track at once", considers the narrator, "but, drunk or sober, mad or sane, good or bad, it isn't Bush religion to desert a mate in a hole; and the boss was a mate of ours; so we stuck to him" (LAWSON, 1984b, p. 59). After some more time struggling on the road, Bob 
dies "in the horrors of drink" (LAWSON, 1984b, p. 59). Andy's "sacrifice" consists of lying to Mrs. Baker. In the name of the spirit of mateship, Andy must "spin a yarn" about Bob's last days, substituting the sordid details of his decline for clichés such as "They thought a lot of him over there. Everybody was fond of him" and "He never touched a drop after he left Solong" (LAWSON, 1984b, p. 63).

In Lawson's stories, the bush is invariably "no place for a woman" (one of Lawson's stories has exactly this title) and his female characters, as Kay Schaffer (1988, p. 123-124) claims, "personify the disintegrating influence in the bush. They become metaphors for defeat, succumbing to exhaustion, despair and death, as they mirror man's dilemma." Even Mrs. Baker, Timothy Clark (2007, p. 23-24) observes, who lives in a small village in the interior and is, thus, a semi-urban character, needs to be protected and deluded to keep her image as "the loving wife of a brave man who heroically succumbed to the perils of the frontier". Furthermore, "her being kept in that role also helps sustain the lie of the man's heroism and selfsacrifice". Ultimately, lying contributes to maintaining the behaviour ideals of the Australian tradition.

The story has an amusing ending as Mrs. Baker's younger sister, Miss Standish - a clever city girl who immediately catches Andy in his lie - follows the mates to the gate and kisses each one on the mouth, thus justifying her behaviour: "You are good men! I like the Bushmen! They are grand men - they are noble" (LAWSON, 1984b, p. 65). The fact that the narrator makes a point in announcing that Miss Standish contributes to the Bulletin adds, according to Clark (2007, p. 23), an ingenious and ironic meta-fictional touch to the story, pointing at the "dichotomy between those who know the truth but require others who need to be lied to and those who need to be lied to, Mrs. Baker, city people on the whole." From that point of view, the ending of "Telling Mrs. Baker" could be viewed as a parody of the way in which Australian society, by means of its nationalist press and the voluntary credulity of its reading public - i.e., the creation of imagined communities - perpetuated the "pleasant lies" of rural tradition and mateship. Accordingly, for Lorenzo Veracini (2011, p. 89-90), historical and fictional representations of Australia as egalitarian and classless serve as a "screen memory" to 
conceal the real conditions of settler colonialism, involving cruelty and genocide towards the Indigenous Others, as well as a profoundly gendered society.

Irony and black humour are strong cultural tendencies in Australia. ${ }^{2}$ According to Glen Lewis (1987, p. 15), the former derives from the British taste for the "understatement", and the latter is a legacy of the need for self-preservation against cruelty and injustice of penal colony times. The inhospitable conditions of the land, alternating droughts and floods able to completely destroy one's work in a matter of days also left bushmen, in Tom Moore's (1971, p. 174-175) analysis, with two choices: to laugh or to cry. Their pragmatism and refusal to feel sorry for themselves usually led them to the first option.

A combination of understatement, black humour and self-mocking sets the tone for "The Union Buries its Dead", the story of Lawson's that might serve as the best counterpoint to "Send Round the Hat". Matthews (1972, p. 5) observes that this narrative at first "seems to be little more than a solid piece of cynical pessimism". The initial style is documental and denotes the lack of the narrator's personal involvement, despite the first-person point of view:

While out boating one Sunday afternoon on a billabong across the river, we saw a young man on horseback driving some horses along the bank. He said it was a fine day, and asked if the water was deep there. The joker of our party said it was deep enough to drown him, and he laughed and rode farther up. We didn't take-much notice of him (LAWSON, 1984a, p. 265).

When the man is found dead by drowning, there are few clues about his identity. Some General Labourer's Union documents state his suppose name, age and religion: "Roman". The double iconoclastic purpose of the story (which demolishes both the "sacred" institutions of religion and union loyalty) is revealed next: "The departed was a 'Roman' and the majority of the town were otherwise - but unionism is stronger than

2 On the role of irony in Australian fiction, cf. SCHEIDT, Déborah. Irony and the status of the Australian hero in True history of the Kelly Gang, by Peter Carey. Estudos AngloAmericanos, v. 37, 2013. creed. Drink, however, is stronger than unionism" (LAWSON, 1984a, p. 265).

Following that hierarchical order (as a defender of egalitarianism, the only hierarchy accepted by Lawson seems to be of a parodic nature), under the midday sun, the deceased man's recently acquired mates get dispersed, as the funeral 
procession passes along the town's several pubs (which have, in decorum, closed the front doors, but not the back ones).

All the details of the ceremony that follows are, in Matthews's (1972, p. 6) words, "inverted, twisted away from the normal associations of such an occasion to become a new, grotesque ritual". The priest is called a "devil", the sound of the dirt lumps hitting the coffin is not "any different from the fall of the same things on an ordinary wooden box" (LAWSON, 1984a, p. 266), the "mourners" do not know each other and not even the deceased's real name. The name inscribed on the gravestone, it is eventually revealed, is not the real one, and, even so, it is quickly forgotten:

We did hear, later on, what his real name was; but if we ever chance to read it in the "Missing Friends Column", we shall not be able to give any information to heart-broken mother or sister or wife, nor to anyone who could let him hear something to his advantage - for we have already forgotten the name (LAWSON, 1984a, p. 267).

For Morgan (1988, p. 242), what makes this story so welladjusted to the brutalising environment of the Australian outback is the fact that Lawson erodes, from the outset, any positive meaning that might be attributed to the funeral, deconstructing the metaphorical and sentimental role that death usually plays in romantic literature. In poetry, as well as in many typically Victorian fiction, sunsets and winter are the appropriated backgrounds for melancholy and death.

In "The Union Buries Its Dead", the famous metafictional passage centred on the absences - of the typical scenery, characters (real mates) and atmosphere - maintains the ironic and nihilistic tone, whilst it also works, according to Matthews (1972, p. 9), as a critical outburst from a non-conformist and lonely writer in the Australian literary scenario:

I have left out the wattle - because it wasn't there. I have also neglected to mention the heart-broken old mate, with his grizzled head bowed and great pearly drops streaming down his rugged cheeks. He was absent - he was probably "Out Back." For similar reasons I have omitted reference to the suspicious moisture in the eyes of a bearded bush ruffian named Bill. Bill failed to turn up, and the only moisture was that which was induced by the heat. I have left out the "sad Australian sunset" because the sun was not going down at the time. The burial took place exactly at mid-day (LAWSON, 1984a, p. 267). 
The narrator's attempt to distance himself from the situation is reinforced by the structure of the story itself. Mitchell observes that the narrator that recognises himself as part of a collective "we" in the first paragraphs, at a certain point leaves the group to observe, from a certain distance, his colleagues' supposed indifference. And, in the excerpt quoted above, he goes back a step further to overtly assume the role of the critical storyteller.

A supposed account of union loyalty becomes, in Mitchell's view (1981, p. 71-72), a farce, in which the scenery and the facts are trivialised, and even the language tries to keep any sentimentality at bay. The story might be interpreted as criticism to what makes bushmen seem to have lost their sensitivity, when, in fact, "what we discern in the narrator is not insensitivity but the pose of insensitivity, as tough to guard himself against the impulse of true feeling".

Like "Telling Mrs. Baker", this story has a metafictional component. But while the former parodies the fictional pact required for the idealisation of mateship as an Australian value, the focus on the absences and on the human deficiencies that threaten an essentially noble code of conduct characterise "The Union Buries Its Dead" as an inverted hyperbole.

It is possible to notice in this group of stories, the subtlety or delicacy of touch that A. A. Phillips (1970, p. 112) considers to be Lawson's most outstanding quality as a short story writer. And corroborating Heseltine's (1972) theory, rather than a blind defence, or the adherence to a univocal approach to mateship, several facets of the theme permeate these narratives, including varying levels of sentimentality, idealisation and deglamourisation, humour, irony, sarcasm, and self-mockery.

Mateship, both as a concept and as a colloquialism, has remained an important factor in Australian history. In Britain it had been associated with the activity of labour parties before it was brought to Australia by the first convicts. It quickly adapted to the local environment and, from the bush, it was taken to World War I, where it evolved into the Australian soldiers' code of conduct of "never leaving a man behind". It crossed the twentieth century and nearly became officially recognised as an Australian value in the Constitution in the 1980s, as a suggestion of Prime Minister John Howard (PAGE, 2002, p. 193-194). Even in the $21^{\text {st }}$ century, whereas it is often 
criticised, its presence is constantly reiterated in the daily life of Australians, considering that, linguistically, the word "mate" remains the most commonly used Australianism, serving as a "universal vocative" (TURNER, 1972, p. 112).

However, the analysis of the stories above attempted to demonstrate that even Lawson, one of the greatest enthusiasts of the principle of mateship, could see its shortcomings and the considerable gap between mateship as an ideal of Australian egalitarianism and democracy and its realisation. Lawson's fictional representation of several of the overtones of the term preceded more openly critical debates on the value of mateship for Australian society that have been happening since the 1970s, such as the questioning of the exclusion of women (DIXSON, 1999) and other minorities (THOMPSON, 1994; PAGE, 2002; LEE, 2004) from its scope.

\section{BIBLIOGRAPHY}

ANDERSON, Benedict. Comunidades imaginadas. São Paulo: Companhia das Letras, 2009.

CARTER, David; WHITLOCK, Gillian. Institutions of Australian literature. In: WALTER, James (ed.). Australian studies: a survey. Melbourne: Oxford University Press, 1989.

CLARK, Timothy. The challenge of the meta-contextual: Henry Lawson's "Telling Mrs. Baker" and some animal questions for Australia. Oxford Literary Review, v. 29, n. 1, 2007.

DIXSON, Miriam. The real Matilda: woman and identity in Australia - 1788 to the present. Sydney: University of New South Wales Press, 1999.

GOODALL, Peter. High culture, popular culture: the long debate. Sydney: Allen \& Unwin, 1995.

GREEN, Henry Mackenzie. A history of Australian literature. V. 1. Sydney: Angus and Robertson, 1968.

HARPER, Melissa. The ways of the bushwalker: on foot in Australia. Sydney: University of New South Wales Press, 2007. 
HESELTINE, Harry. Saint Henry - our spostle of mateship. In: RODERICK, Colin (Ed.). Henry Lawson criticism: 1894-1971. Sydney: Angus and Robertson, 1972.

KIERNAN, Brian. Introduction. In: LAWSON, Henry. A camp-fire yarn: complete works 1885-1900. Sydney: Lansdowne Press, 1984.

LAWSON, Henry. A camp-fire yarn: complete works 1885-1900. Sydney: Lansdowne Press, 1984a.

A fantasy of man: complete works 1901-1922. Sydney: Lansdowne Press, 1984b.

LAWSON, Sylvia. The Archibald paradox: a strange case of authorship. Ringwood: Penguin, 1987.

LEWIS, Glen. Australian movies and the American dream. New York: Praeger, 1987.

LEE, Christopher. City bushman: Henry Lawson and the Australian imagination. Fremantle: Curtin, 2004.

MATTHEWS, Brian. "The nurse and tutor of eccentric minds": Some developments in Lawson's treatment of madness. In: RODERICK, Colin (Ed.). Henry Lawson criticism: 1894-1971. Sydney: Angus and Robertson, 1972.

MITCHELL, Adrian. Fiction. In: KRAMER, Leonie (Ed.). The Oxford history of Australian literature. Oxford: Oxford University Press, 1981.

MORGAN, Patrick. Realism and documentary. In: HERGENHAN, Laurie. (Ed.). The Penguin new literary history of Australia/Australian literary studies (special issue), v. 13, n. 4, October, 1988.

MOORE, Bruce. Speaking our language: the story of Australian English. Melbourne: Oxford University Press, 2008.

MOORE, Tom Inglis. Social patterns in Australian literature. Berkeley: University of California Press, 1971. 
PAGE, Jim. Is mateship a virtue? Australian Journal of Social Issues, Sydney, v. 37, n. 2, May. 2002.

PALMER, Vance. The legend of the nineties. Melbourne: Melbourne University Press, 1954.

PHILLIPS, Arthur Angell. Henry Lawson. New York: Twayne Publishers, 1970.

. The Australian tradition: studies in a colonial culture. Melbourne: Cheshire-Lansdowne, 1966.

RODERICK, Colin. Henry Lawson: poet and short story writer. Sydney: Angus \& Robertson, 1966.

Henry Lawson: the master storyteller. Sydney: Angus \& Robertson, 1985.

ROWLEY, Sue. Imagination, madness and nation in Australian bush mythology. In: DARIAN-SMITH, Kate et al. (Ed.). Text, theory, space: land, literature and history in South Africa and Australia. New York: Routledge, 1996.

SCHAFFER, Kay. Women and the bush: forces of desire in the Australian cultural tradition. Cambridge: Cambridge University Press, 1988.

THOMPSON, Elaine. Fair enough: egalitarianism in Australia. Sydney: University of New South Wales Press, 1994.

TURNER, George Winson. The English language in Australia and New Zealand. London: Longman, 1972.

VERACINI, Lorenzo. Settler colonialism: a theoretical overview. Basingstoke (UK); New York: Palgrave Macmillan, 2011.

WARD, Russel. The Australian legend. Melbourne: Oxford University Press, 1966.

WILDING, Michael. Henry Lawson's short stories. In:

The radical tradition:

Lawson, Furphy, Stead. Townsville: Foundation for Australian Literary Studies, 1993. 


\section{Resumo}

\section{Mateship e igualitarismo nos contos de Henry Lawson}

Mateship é um elemento importante da chamada "Tradição Australiana" na literatura. Refere-se a um vínculo especial entre homens que percorrem as áreas rurais conhecidas na Austrália como "the bush" ou "the outback". Este artigo examina alguns dos contos de Henry Lawson que trazem esse elemento, com ênfase especial nas diferentes conotações que o termo pode assumir para o autor, especialmente com relação à temática do igualitarismo. $O$ artigo considera como o periódico Bulletin, o qual "descobriu" Lawson e publicou vários de seus contos, foi relevante para a promoção de um modelo particular de democracia na Austrália e um estilo característico para a literatura local. O artigo também reflete sobre como a disseminação dos contos de Lawson por meio de periódicos na última década do século XIX contribuiu para a criação do que Benedict Anderson chama de "nation-ness".

Palavras-chave: Mateship. Igualitarismo. Henry Lawson. Conto australiano. 